\title{
CPS-SLAM による大規模環境のレーザ観測の自動計画手法
}

\author{
大 島 漱一郎* 永 倉 翔 吾* 鄭 龍 振*
岩 下 友 美* 倉 爪 亮* \\ Automatic Planning of Laser Measurements for a Large-scale Environment \\ using CPS-SLAM System
}

\author{
Souichiro Oshima*, Syogo Nagakura*, Jeong Yongjin*, \\ Yumi Iwashita* and Ryo Kurazume*
}

\begin{abstract}
In recent years, several low-price 3D laser scanners are being brought to the market and 3D laser scanning has been widely used in many applications. For example, 3D modeling of architectural structures and digital preservation of cultural heritages are typical applications for 3D laser scanning. Despite of the development of light-weight and high-speed laser scanners, complicated measurement procedure and large measurement time are still heavy burden for the widespread use of laser scanning. We have proposed a robotic 3D scanning system using multiple robots named CPS-SLAM, which consists of parent robots with a 3D laser scanner and child robots with corner cubes. This system enables to perform 3D laser scanning without complicated post-processing procedures such as ICP, and large-scale 3D models can be acquired by an on-board 3D laser scanner from several positions determined precisely by the localization technique named Cooperative Positioning System, CPS. This paper proposes an automatic planning technique for an efficient laser measurement for the CPS-SLAM system. By planning a proper scanning strategy depending on a target structure, it is possible to perform laser scanning efficiently and accurately even for a large-scale environment. Proposed technique plans an optimal scanning strategy automatically by taking several criteria, such as visibility between robots, error accumulation, and efficient traveling, into consideration. We conducted computer simulation and outdoor experiments to verify the performance of the proposed technique.
\end{abstract}

Key Words: Laser Measurement, Multiple Robots, 3D Modeling, Automatic Sensing Planning

\section{1.はじめに}

FARO Focus 3D や Lieca Scanstation, TOPCON GLS1500 など，三次元レーザスキャナの低価格化に伴い，レーザ計 測は土木建築分野での現況確認, 建造物のモデリングや文化財 のデジタル化など，様々な分野で応用が進められている.

一般に，建造物や大型文化財など大規模な対象をレーザ計測 する際，一地点から観測される領域は限られることから，複数 の地点に移動して繰り返しレーザ計測を行い, あらかじめ設置 したマーカや Iterative Closest Point（ICP）法等により, 複数 の計測デー夕を後処理で位置合わせする手法が用いられる。こ の際，次にどの地点に移動すべきか，すなわち大規模環境にお けるレーザ観測計画は，観測作業の効率化には重要な要素であ る。しかし，これまでは作業者の経験により決定されているの

原稿受付 2014 年 5 月 13 日

*九州大学

${ }^{*}$ Kyushu University

一本論文は有用性（システム設計・構築分野）で評価されました。
が実情である.

これに対し，もしこれまでの計測履歴に基づき設定された評 価指標により, 次回以降の最適な観測位置が自動的に立案され るならば，作業員の熟練度に寄らず観測作業の効率化が実現で きる.

これまで，筆者らはロボットに搭載したレーザスキャナにより， 大規模環境におけるレーザ計測と位置同定を繰り返し実現する, 大規模環境のレーザ計測のための群ロボットシステム（CPSSLAM）を提案し, 太宰府天満宮の三次元計測やトンネル工事 現場での出来形計測などの実証実験により，その有効性を確認 してきた $[1] 〜[3]$.

提案した CPS-SLAM は大規模対象に対する高精度な三次 元レーザ計測システムとして極めて有効な手法である。例えば SLAM や GPS，オドメトリを用いたレーザ計測システムと比 較した場合の優位な点として, 以下の点が挙げられる。

・SLAM により得られるモデルや経路の高精度化には，一般 に閉ループとなる経路が必要である。これに対し, CPSSLAM は閉ループがなくとも高精度な位置同定が可能であ 
る。例えば鄭ら [3] は，屋内環境では $210[\mathrm{~m}]$ 移動後の誤差 が $98[\mathrm{~mm}]$, 屋外では $313[\mathrm{~m}]$ 高低差 $5[\mathrm{~m}]$ 移動後の誤差 が $116[\mathrm{~mm}]$ であることが報告されており，GPS やオドメ トリと比較して圧倒的な高精度である.

- 複数距離画像の位置合わせによく用いられる ICP 法は，通 常人手により大まかな初期位置合わせを行う必要がある. また計測地点が多い場合には後処理の計算コストも膨大と なり，さらにICP 法により精度良く位置合わせを行うため には，各計測地点で得られた三次元点データに共通して特 徵的な形状が含まれ，かつ点データの分布が十分に重なる ように測定を密に行わなければならない.これはICP 法を 用いたSLAM にも当てはまる。 これに対し, CPS-SLAM は点群そのものを位置合わせに使う必要がなく，重なりが まったくなくても統合したモデルが生成できる.

- RTK 方式（リアルタイムキネマテイック方式）やVRS 方 式（仮想基準点方式）など高精度な GPS は，衛星の見通 せない建物の間や屋内環境，地下街では用いることができ ない.これに対し，CPS-SLAM は屋内，屋外を問わず適 用可能である。

本システムは，環境計測用レーザスキャナと測量用トータルス テーションを搭載した 1 台の親ロボットと, 全方位コーナキュー ブを搭載した 2 台の子ロボットからなる。親ロボットは 2 台の 静止した子ロボットまでの距離と方位を計測することで，親ロ ボット自身の位置を同定するままた子ロボットも同様に，静止 した親ロボットまでの距離と方位から，自身の位置を同定する. さらに親ロボットに搭載した環境計測用レーザスキャナにより, 同定された位置から計測を繰り返すことで，複数地点で計測さ れたレーザ計測データを世界座標系に変換，統合する.

このシステムにおいても，これまで観測計画の立案は，主に オペレータや作業者の経験に基づいて行われていた。このため, 効率性や最適性に対する数值的な裏付けがなく，オペレータの スキルによっては，例えば観測の重複が発生したり，不必要な移 動，観測のために作業時間が長くなる恐れがあった。これに対 し，観測回数や観測精度などの客観的指標に基づき，定量的に 最適化された経路が得られる観測計画の自動立案は，オペレー 夕の負荷低減のみならず，計測対象やオペレータのスキルによ る計測回数，精度のばらつきを極力抑え，また無駄な観測を省 き作業時間を短縮するのに有効であると考えられる。そこで本 論文では，この大規模環境におけるレーザ計測のための群ロボッ トシステム（CPS-SLAM）に対して，ロボット間の見通しや位 置同定誤差の抑制，効率的な移動計画などの諸条件を満たした 観測計画を自動的に立案する，大規模環境におけるレーザ観測 計画の自動化手法を提案する。

提案手法は，オペレータの経験や勘に基づく従来のレーザ観 測計画と比較し，以下のような利点がある.

（1）観測回数や観測精度など客観的指標に基づき，数值的に裏 付けされた観測計画が得られる

（2）計測対象やオペレータのスキルによる計測回数，精度のば らつきが抑えられる

またこのほかにも，以下のような効果が期待できる.

（3）無駄な観測を省き作業時間を短縮できる
（4）オペレータの負荷低減や計測作業に安心感を与える 上記 4 については，後述する実環境での実験において説明する.

\section{2. 関 連 研 究}

カメラによる監視など，センサの最適配置計画や最適観測計 画の問題は，計算幾何学やコンピュータビジョンの分野で古く から研究されてきた $[4] 〜[6]$. 一般に，この問題は，環境や物体 の幾何情報が既知である場合と未知である場合に大別できる. 幾何形状が既知である場合の最適観測計画は, 死角のない広域 監視を実現するセンサ配置や，効率的な外観検査などに用いら れる。特に屋内環境でのセンサ（監視要員）の最適配置問題は $\lceil$ Art gallery problem」と呼ばれ, 計算機科学の分野で研究され てきた [7] [8]. Allen ら [9] は，三次元の都市空間で死角のない 観測を行うためのインタラクティブなセンサ配置手法を提案し た. Topcuoglu ら [10] はより広大な地形図を対象に，センサの 最適配置と観測の秘匿性を両立する手法を提案している。一方, Chen [11], Scotto [12] らは, 三次元距離センサを用いて既知 形状の対象物上の特徴を, 効率的かつ正確に計測するための最 適観測計画手法を提案している。 またPrietoら [13] は，CAD データが与えられた対象を，距離センサを用いて精度よく検査 するための最適観測計画について議論している.

一方，幾何情報が未知な場合には，未知物体の形状計測のため の観測計画 [14]〜 [18] や，センサを積極的に移動させて物体認識 を行う能動的物体認識 [19] [20] などが提案されている. Okamoto ら [21] は，観測を連続的に繰り返して観測結果を統合し，確率 的にモデルを表現して次時刻の最適観測位置を決定する基本的 枠組みを提案した，Li ら [18] はモデルの不確実性を示す情報エ ントロピーを用い, 得られる情報量が最も多いと予想される点 を Next Best View（NBV）として選択した。

本論文で取り扱う内容は，後者の幾何情報が未知な場合に属 する，しかし上述した従来手法では，レーザスキャナやカメラ は，マニピュレータなどにより空間内の任意の位置に正確に移 動できることを仮定している。このため，位置同定精度などは 考慮せず，できるだけ未知領域が減少すること，できるだけ移 動・観測回数が少なくなることを目標に観測が計画されていた. 一方，提案システムでは，観測位置を変更する際，正確な位置 は後述する協調ポジショニングシステムにより計測される. し たがって，協調ポジショニングシステムを実現するために，上 記に加えてロボット間の見通しの確保という新たな条件を考慮 する必要がある。このため，観測位置を自由に選択できる従来 手法とはまったく異なるアプローチが必要となる.

\section{3. 大規模環境のレーザ計測のための群ロボットシステム (CPS-SLAM)}

大規模環境におけるレーザ計測のための群ロボットシステム (CPS-SLAM) では，各ロボットの自己位置は協調ポジショニ ング法 (Cooperative Positinoning System, CPS) により同定 される. CPS の動作例を Fig. 1 に示す。この例は, 1 台の親口 ボットと 2 台の子ロボットからなる群ロボットシステムにおい て, 親ロボットに搭載したレーザ距離測定器（トータルステー ション）により，子ロボットおよび親ロボット自身の位置を計 


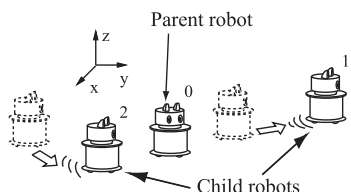

(1) Robots 1 and 2 move.

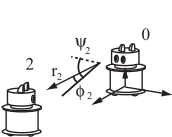

(3) Robot 0 measures the position of robot 2

Fig. 1 Cooperative Positioning System, CPS

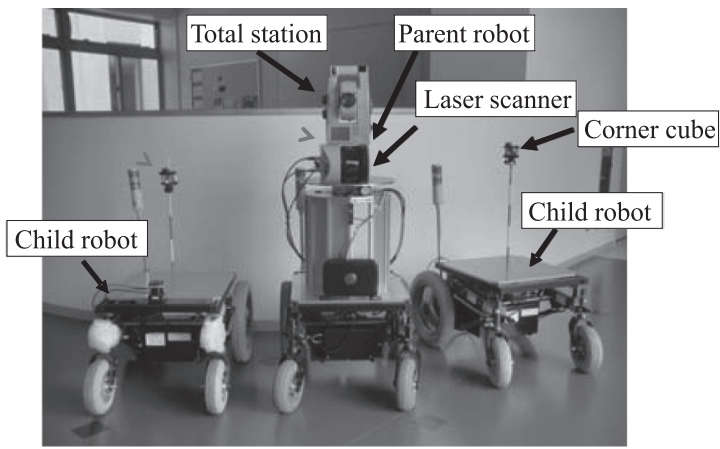

Fig. 2 CPS-SLAM machine model, CPS-VII

測するものである。まずあらかじめ，初期位置を計測した状態 で親ロボットを静止させ，

（1）子ロボット $1 ， 2$ を移動させた後，停止させる

(2) 親ロボットに搭載した測定器により，子ロボット 1 までの 相対距離, 方位角, 仰角を計測し, 子ロボット 1 の位置を 同定する

（3）（2）と同様に，子ロボット 2 までの相対距離，方位角，仰 角を計測し，子ロボット 2 の位置を同定する

（4）親ロボットを移動させた後，停止させ，親ロボットに搭載 した測定器により子ロボット 1,2 までの相対距離，方位 角，仰角を計測して，親ロボットの位置を三辺測量法によ り同定する

という動作を繰り返す.

CPS-SLAM では，親ロボットにトータルステーションに加 えてレーザスキャナを搭載し，上記 CPS により位置が同定され た複数地点から環境構造を繰り返しレーザ計測する。得られた 局所的な三次元モデルは, CPS により計測位置が同定されてい ることから，簡単な座標変換により世界座標系へ変換でき，大 規模な環境モデルも ICP (Iterative Closest Point) 法などの 位置合わせのための後処理を用いることなく，容易に得られる.

Fig. 2 に，これまでに構築したレーザ計測ロボット群 (CPSVII）を示す.このシステムは，トータルステーションとレーザ スキャナを搭載した 1 台の親ロボットと, 全方向コーナキュー ブを搭載した 2 台の子ロボットからなる. Fig. 3 に, Fig. 2 の システムを用いて計測した大規模建造物の三次元モデルを示す. 本論文では, Fig. 2 に示した CPS-VII に対して, 計測対象に

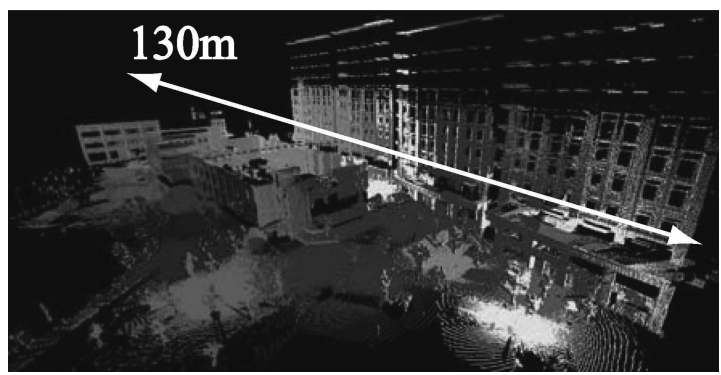

Fig. 3 3D model of large building

応じて計測位置を自動計画し，効率的なレーザ計測を実現する 手法を提案する.

\section{4. 自動計画手法}

計測作業の自動化には，無駄のない効率的なレーザ計測のみ ならず，様々な状況において解が必ず得られる信頼性，誤差の 蓄積の低減や移動距離の最小化, ロボット同士や壁などの障害 物との衝突回避など，様々な要素を考慮する必要がある.

そこで提案手法では，すでに数回，レーザ計測が繰り返され， 環境構造の一部がすでに得られている状況を想定し, それまで に計測された一部の環境構造から次回の計測で最も多く新たな 観測データが得られると予想される地点を複数選択し, そこに到 達するまでの移動距離を基準に最適な地点を絞り込むアプロー チを取る。

また，提案した群ロボットシステム（CPS-SLAM）では，親 子ロボットが交互に観測を繰り返すことから，位置同定時には 常に両者が見通せる必要がある。しかし複雑な環境などでは，移 動開始位置と絞り込まれた目標位置との間で，この条件が満た されない場合も多い.

そこで提案手法では，移動開始位置と目標位置間で見通し条 件が満たされない場合には, Visibility Graph [23] [24] を用い て開始一目標間の最短経路上にサブゴールを次々に設定し，見通 し条件を満足する経路に細かく分解することで，ロボットの移 動を可能にしている．本論文で提案する手法の概要をFig. 4 に 示す.

以下,

(1) 親ロボットの計測目標位置の自動計画

(2) 子ロボットの移動目標位置の自動計画

のそれぞれに対し，上記手法の詳細を述べる，なお，提案手法で はまずそれまでに計測された三次元環境データを二次元グリッ ド地図に変換し, 二次元地図上で観測計画を立案する.

\section{1 親ロボットの計測目標位置の自動計画}

親ロボットの計測位置としては,

（1）これまでに計測できた領域（既計測領域）と計測していな い領域（未計測領域）の境界に近い

（2）衝突を避けるため，障害物からある程度離れている

(3) 現在位置からの移動距離が短い

（4）新たに計測できる未計測領域が大きい

などの条件を同時に満たす位置が望ましい.しかし，計測対象 領域が広い場合，領域全体を対象として親ロボットの移動目標 


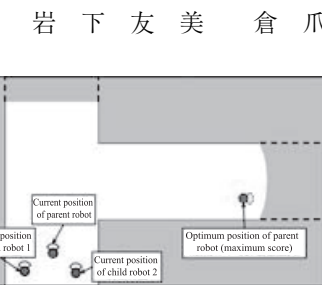

(a)

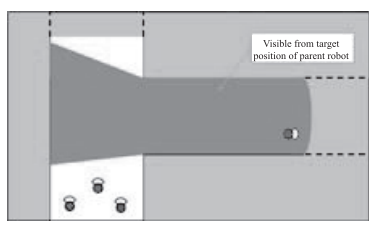

(c)

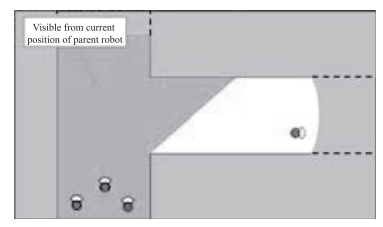

(b)

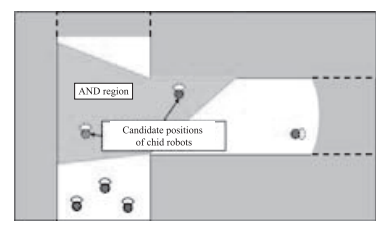

(d)

Fig. 4 Flowchart of automatic planning algorithm

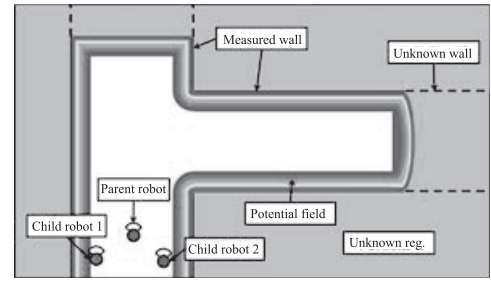

Fig. 5 Problem definition

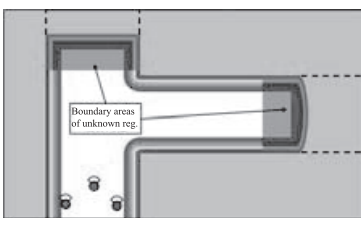

(a)

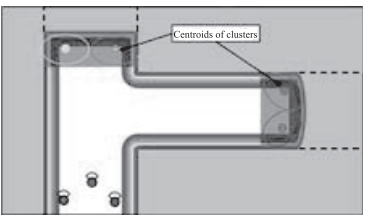

(c)

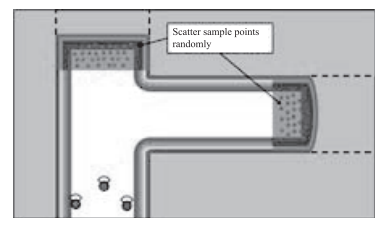

(b)

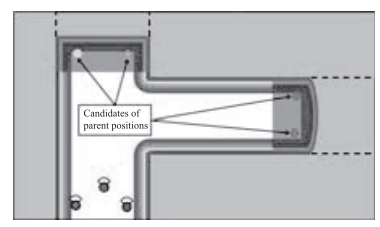

(d)

Fig. 6 Determined candidate positions for parent robot by Kmeans clustering

位置を探索すると，アルゴリズムの実行時間が膨大になる可能 性がある，そのため，提案手法では，親ロボットの目標位置の 探索前に探索領域の絞り込みを行い, 少数の目標位置候補を求 める.

親ロボットの目標位置候補の絞り込みには, K-means 法によ るクラスタリングを利用する. Fig. 5 に問題設定を，Fig. 6 に 絞り込みの手順を示す。具体的には以下の手順に従う.

（1）既計測領域と未計測領域の境界グリッドを見つける.

（2）境界グリッドから一定領域内に一定密度でランダムに候補 点を設定する。

（3）（2）の候補点に対して，クラスタリングを実行する.

（4）（3）のクラスタ中心を親ロボットの目標位置候補とする. ただし，クラスタ数は境界領域の広さに応じて決定する。

Fig. 7 AND region and candidate positions for child robots

次に，得られた目標位置候補から，以下の条件を考慮して最 終的な親ロボットの計測目標位置を決定する.

（1）既計測領域内かつ現在位置から到達可能

(2) 障害物に衝突しない

(3) 親ロボットの現在位置からの移動距離が小さい

(4) 新たに計測できる未計測領域の範囲が大きい

これらの条件を満たす最適な目標位置を探索するため，すべて の目標位置候補を含むグリッドに対して次の評価值を計算する.

$$
G=R \cdot\left(P^{-1}+\alpha \cdot L^{-1}+\beta \cdot S\right)
$$

ここで， $G$ は各目標位置候補の評価值， $R$ はグリッドの状態 を表す 0 または 1 の整数（ 0 =未計測または移動不可， $1=$ 既計 測・移動可),$P$ はポテンシャル（最近傍の障害物からの距離の 逆数, 単位 $: 1 / \mathrm{m}), L$ は親ロボットの現在位置から当該グリッ ドまでの移動距離 (単位：m)，S は当該グリッドから計測可能 な未計測領域の面積 (単位： $\mathrm{m}^{2}$ ), $\alpha, \beta$ は重みを表している. 目標位置候補の中で，この評価值が最大となるものを親ロボッ 卜の移動目標位置として決定する。ただし，ある目標位置候補 から得られる未計測領域の面積 $S$ は，それまでに検出された物 体以外は環境に何も存在しないと仮定し，その目標位置候補か ら全周方向にレーザ計測を行った際に，すでに検出されている 物体に遮られず，かつレーザの最大計測距離より内側に存在す るグリッド数を数え上げることで求めた.

\section{2 子ロボットの移動目標位置の探索}

子ロボットの目標位置探索では，まず候補位置が親ロボット の現在・目標位置の双方から見通せるか否かを考える。これは， ロボットの位置同定に CPS を用いており，親子ロボット間に障 害物が存在すると位置同定が不可能になるためである，本論文 では，Fig.7に示すように，親ロボットの現在・目標位置双方 から見通せる領域を AND 領域と呼ぶ.

AND 領域を算出した後，すべての子ロボットの目標位置を AND 領域内で決定する。この際，考慮すべき条件としては,

(1) AND 領域内の既計測かつ移動可能な位置

(2) 障害物に衝突しない

（3）親ロボットとの距離が一定範囲内

（4）親ロボットから見た，2 台の子ロボットの方位差が $90^{\circ} に$ 
近い位置

などが考えられる．このうち (3) の条件は, 使用するレーザ距 離測定器（トータルステーション）は, 親子ロボット間の距離 が一定以下になると急激に計測誤差が大きくなる $[26]$ ためであ り，(4）は, 子ロボット間の方位差が $90^{\circ}$ に近いほど, CPSで の位置同定誤差の蓄積が小さくなるためである $[26]$.

上記の条件を同時に満足する子ロボットの目標位置を選択す るため, 本手法では以下の評価式を設定し，それが最小となる 2 台の子ロボットの位置を同時に探索する.

$$
G_{c}=P^{-1}+\alpha_{c} \cdot\left|\theta-\theta_{\mathrm{t}}\right|^{-1}+\beta_{c} \cdot\left|D-D_{\mathrm{t}}\right|^{-1}
$$

ここで, $G_{c}$ は子ロボットの目標位置の評価值, $P$ はポテン シャル（最近傍の障害物からの距離の逆数, 単位 $: 1 / \mathrm{m}), \theta$ は 子ロボット間の角度 (単位: $\left.{ }^{\circ}\right), D$ は親ロボットの目標位置か らの直線距離 (単位 $: \mathrm{m}), \theta_{t}, D_{\mathrm{t}}$ は任意の角度, 距離定数, $\delta$ は 0 でない十分小さな実数, 係数 $\alpha_{c}, \beta_{c}$ は重みを表している. ただし， $\theta_{\mathrm{t}}=90^{\circ}$ である。 なお，子ロボットの現在位置がAND 領域に含まれる場合は次の目標位置は求めず，移動しないこと とする.

\subsection{Visibility Graph によるサブゴール探索}

上述した手法では, 親ロボットの目標位置に対して, 見通し などの条件を満たす子ロボットの目標位置候補が存在しない場 合がある，例えば，親ロボットの目標位置が遠く，曲り角を複数 回曲がるなどした場合, 現在・目標位置間で見通し可能な AND 領域が存在せず, 子ロボットの目標位置が得られない. そこで, 親ロボットの移動経路上に目標位置までのサブゴールを設定し, 各サブゴールを親ロボットの目標位置として子ロボットの目標 位置を順次決定することとする。

提案手法では, サブゴールの探索にはVisibility Graph [23] [24] を用いる. Fig. 8 に Visibility Graph の例を示す. Visibility Graph は，ロボットの探索空間内に扔ける障害物の頂点 すべてと, ロボットの現在・目標位置をノードとする可視グラフ を作成し，グラフ探索アルゴリズムを実行することで，ロボット の目標位置までの最短経路を求めるものである。 なお, グラフ の各辺は, その辺で結ばれた頂点間が見通し可能であることを 表す. CPS では, 親子ロボット間で双方が見通せる必要がある が, Visibility Graph ではロボットが各辺上を移動する限り, 確 実に他のロボットを見通すことができる，すなわち，Visibility Graph を用いてサブゴールを決定することで, 確実に目標位置 までの移動経路を求めることが可能となる.Visibility Graph を用いたサブゴール探索の実行手順を以下に示す.

（1）親ロボットの現在・目標位置間に㧈ける AND 領域の有無 を確認する。

（2）AND 領域が存在しない場合, Visibility Graph を生成する.

(3) Visibility Graph 上で親ロボットの目標位置までの最短経 路を探索する.

（4）最短経路上の頂点に対し，目標位置から順に親ロボットの サブゴールを設定する。

（5）設定されたサブゴールに対し，親ロボットの初期位置との AND 領域を求める.

（6）AND 領域が存在する場合には，子ロボットの移動目標位

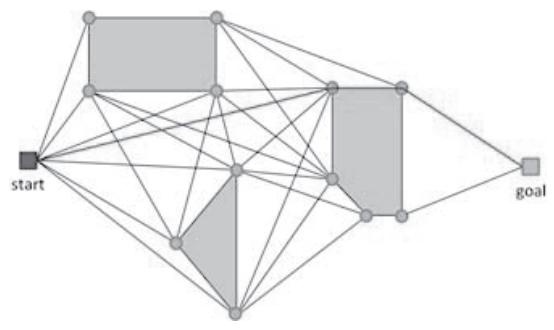

Fig. 8 Visibility Graph

置を探索する，存在しない場合にはサブゴールを一つ前に 進める。

（7）サブゴール間に AND 領域が見つかるまで，(5)〜（6）を 繰り返す。

（8）到達したサブゴールを初期位置として（4）～（7）を繰り返 し，目標位置まで移動する。

\subsection{Voronoi 境界に沿った安全なロボットの移動}

Visibility Graph により決定されたサブゴールを親ロボット が順々に辿ることで, 現在位置から目標位置まで確実にCPS 動作を繰り返しながら移動することができる。しかし実際には, Visibility Graphにより決定された経路は, 障害物の頂点を結 ぶものであり，実際には移動時にサブゴール近傍で障害物に衝 突する可能性が高い。そこで，あらかじめ計測された環境に対 して Voronoi 図 [27] を作成し, そのVoronoi 境界上をロボット が移動することで，障害物から離れた位置を安全に走行する。た だし, 移動するVoronoi 境界は, 始点, 終点, およひVisibility Graph により決定されたサブゴールに最も近いVoronoi 境界上 の点を節とし，それらを結んだ線とする。

\section{5. 実験}

\section{1 計算機シミュレーション}

提案手法の有効性を計算機シミュレーションにより評価した. シミュレーションでは, あらかじめFig. 9 に示す 3 種類の二次 元地図（MAP-A, B, C) を準備し, 各ロボットの初期位置をオ ペレータが手動で設定して, 移動目標位置の探索を開始した。

探索空間となる地図は $800 \times 600$ のグリッドに分割されてお り，グリッドのサイズは $10[\mathrm{~cm}] \times 10[\mathrm{~cm}]$ である，また，親口 ボットの環境測定可能範囲を $20[\mathrm{~m}]$ とした。 なお，シミュレー ションでは地図は事前に準備されているが, ロボットはこの地 図の情報は一切持たず，それまでに計測された情報のみを用い て観測計画を立案する。一例として, MAP-A に対する各ロボッ トの移動軌跡を Fig. 10 に示す.

\section{1 .1 親ロボットの移動目標位置の選択}

4.1 節で提案した親ロボットの移動目標位置の選択法に対し, 式（1）のパラメータ $\alpha, \beta$ を変えてシミュレーションを行い, それぞれのパラメー夕に対する親ロボットの移動軌跡の変化を 調べた.

シミュレーションは,

a）親ロボットの移動距離 $L$ をできるだけ小さくする $(\beta=0)$

b）目標位置で計測可能な未計測領域 $S$ をできるだけ大きくす る $(\alpha=0)$ 


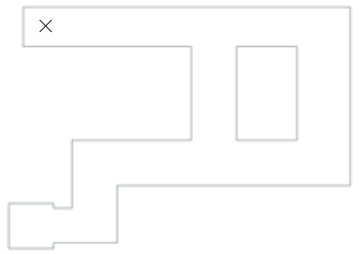

(a) Map A

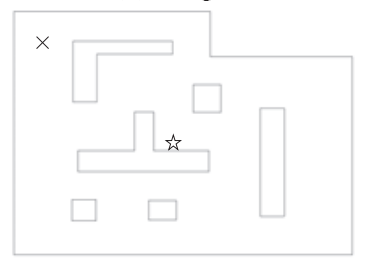

(c) Map C

Fig. 9 MAP A, B, and C

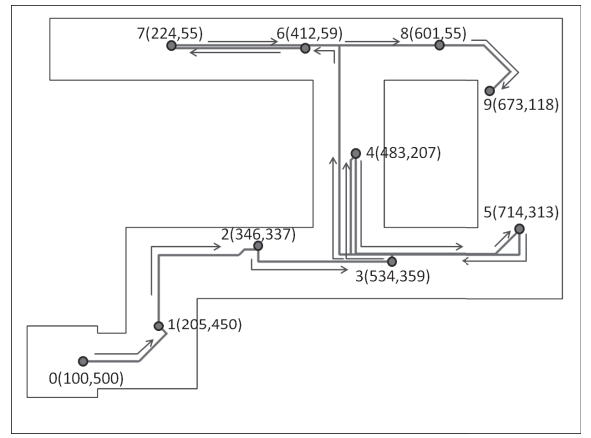

Parent robot

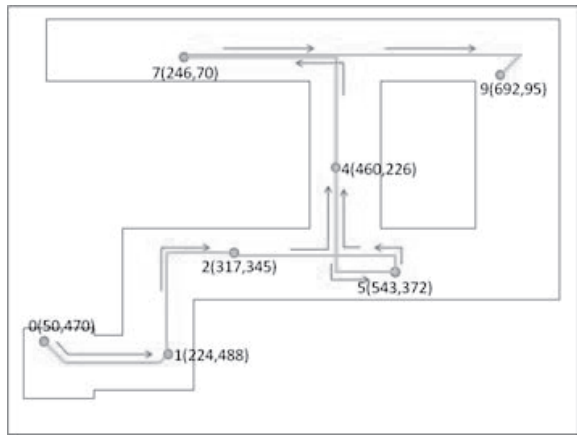

Child robot 1

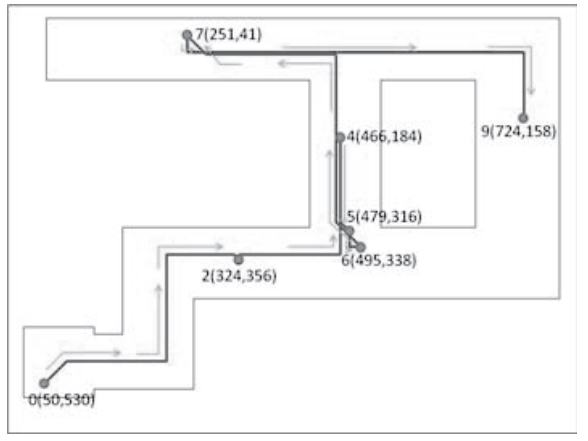

Child robot 2

Fig. 10 Planned trajectories of parent and child robots for MAP A
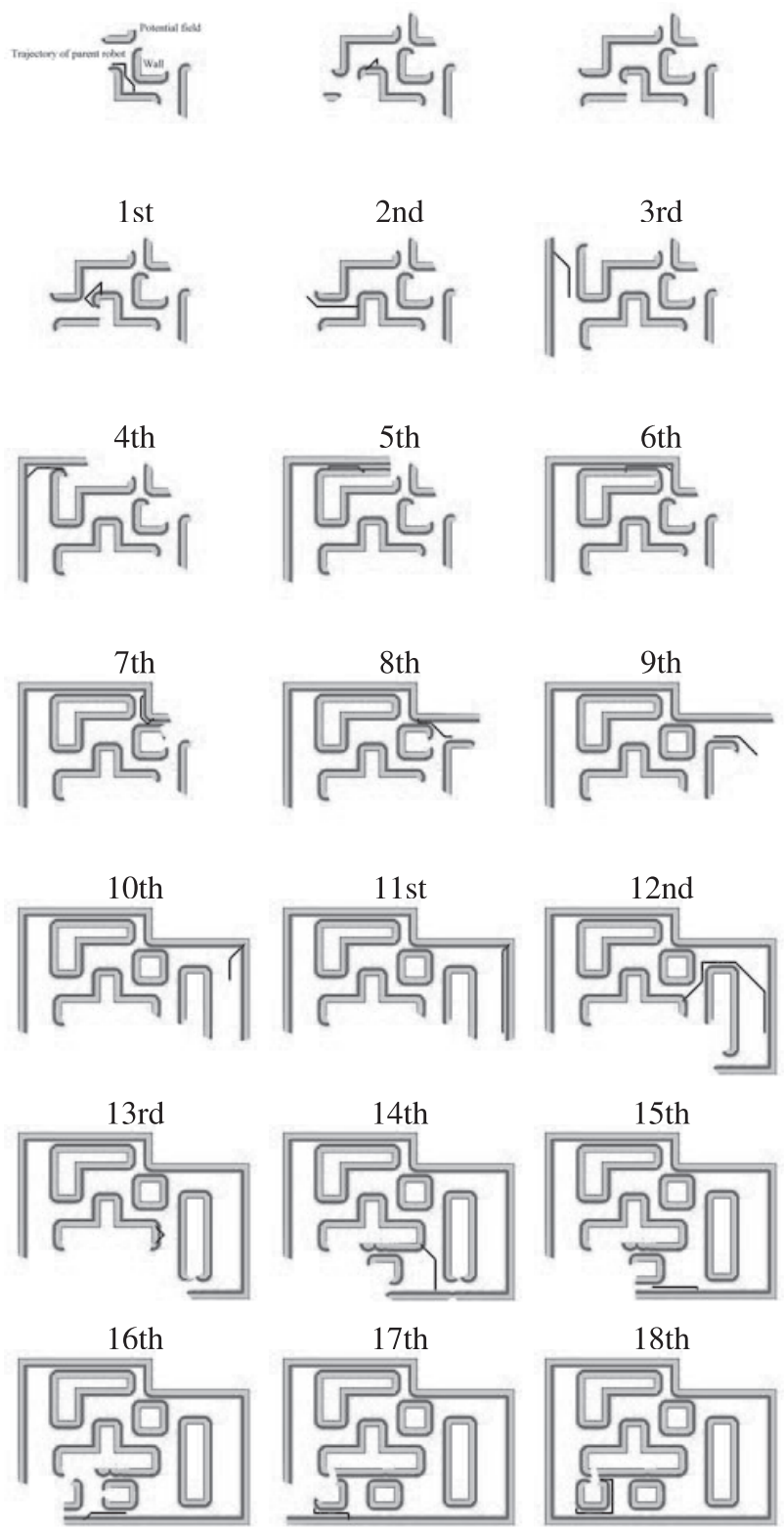

22nd

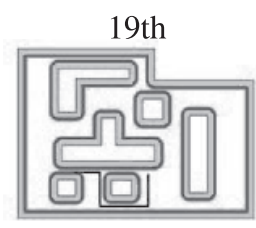

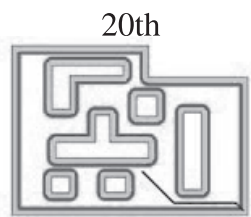

23rd
Fig. 11 Measured map and trajectories of parent robot in case that a closest target position is selected $(\beta=0)$ for MAP C

の 2 種類に対して行った.

MAP-C に対して, 親ロボットの初期位置を Fig. 9 (c) の星印 として観測計画を自動計画した場合の環境地図の獲得の様子を

Fig. 11 およびFig. 13 に，そのときのロボットの移動軌跡を

Fig. 12，およびFig. 14, 15 に示す.

a）親ロボットの移動距離 $L$ を小さくするように目標位置を 


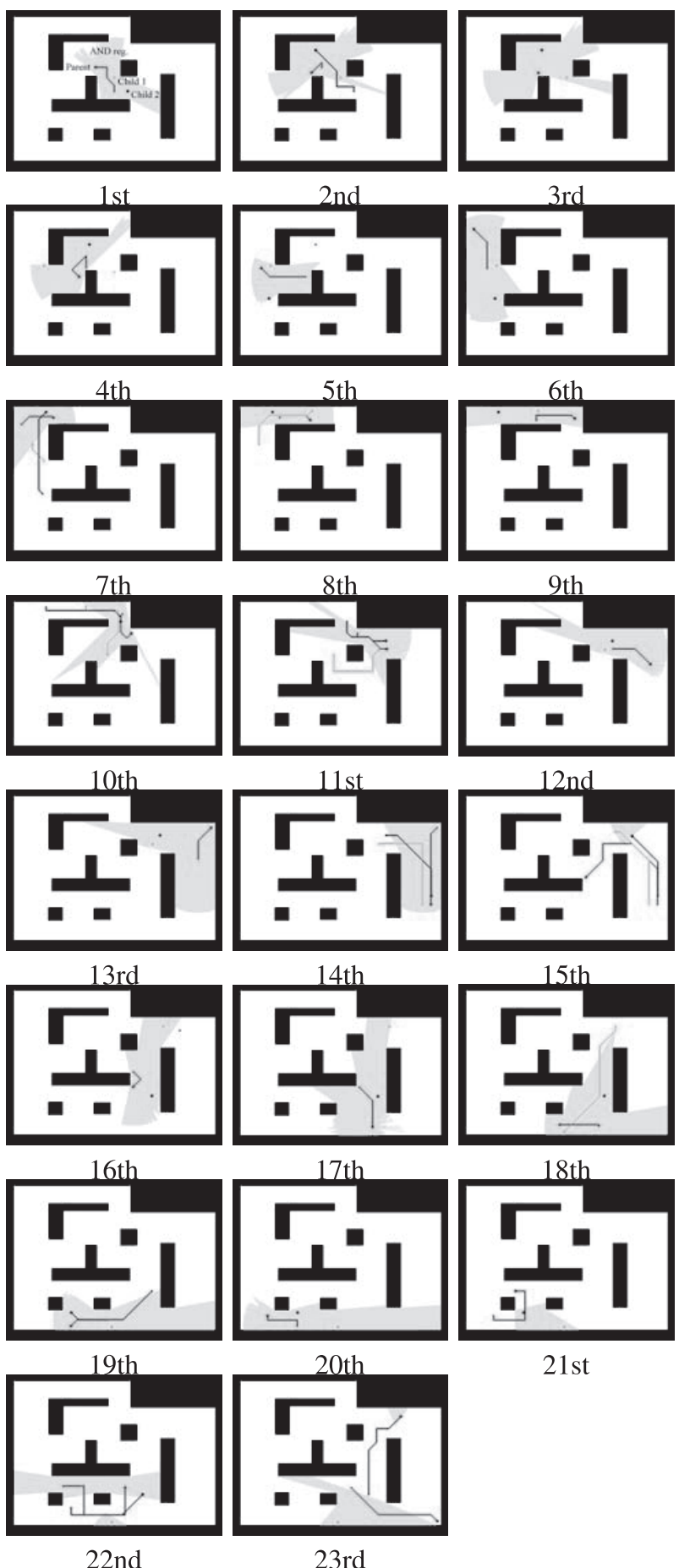

Fig. 12 Trajectories of robots in case that a closest target position is selected $(\beta=0)$ for MAP C

選択した場合（ $\beta=0$, Fig. 11，12)，離れた目標位置は選択さ れないため，見通せない目標位置が選択されることがなく，サ ブゴールの探索は行われていない (Fig. 12)。しかし，一度に 計測される領域が狭く，全域の取得に23 回の移動，計測が必 要であった（Fig. 11）。一方, b) 目標位置で計測可能な未計測 領域 $S$ を大きくするように目標位置を選択した場合 $(\alpha=0$, Fig. 13，14，15)，移動距離が長くても計測範囲ができるだけ
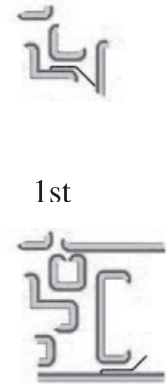

4th
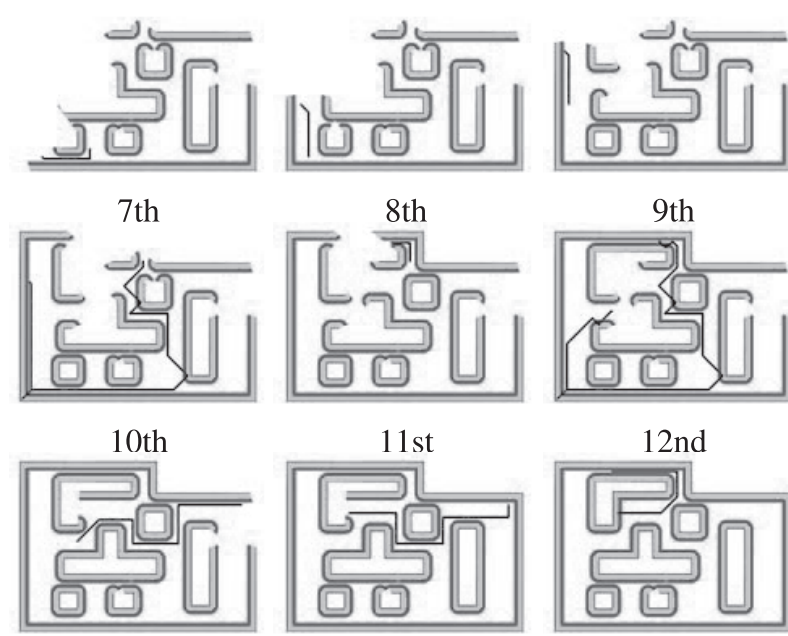

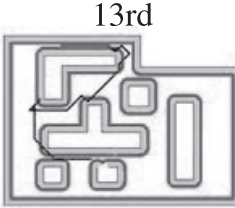

16 th

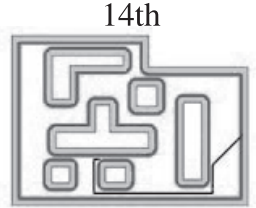

17 th

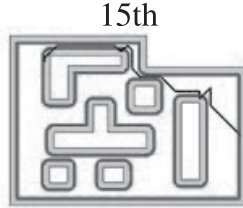

18th
Fig. 13 Measured map and trajectories of parent robot in case that a target position where a measurable area is maximized is selected $(\alpha=0)$ for MAP C

大きくなる目標位置が選択されたため, 計測 10 回め, 12 回め, 16 回めでそれぞれ Visibility Graph によるサブゴール探索が 行われている（Fig. 14，15)。しかし全域の取得に必要な計測 回数は少なく, 18 回の移動，計測で計測が終了した (Fig. 13). Fig. 11（ $\beta=0 ）$ と Fig. 13（ $\alpha=0 ）$ を比較すると, Fig. 13の ほうが Fig. 11 に比べて, 親ロボットの 1 回の移動距離が長い

ことが分かる.

さらに，MAP-C に対して，a）親ロボットの移動距離 $L$ を小 さく $(\beta=0)$, またb) 目標位置で計測可能な未計測領域 $S$ を 大きく $(\alpha=0)$ するように目標位置を選択した場合の移動距離 (回数にサブゴール間の移動も含む) と計測領域（計測可能領域 のカバー率・回数にサブゴール間の移動は含まない）を Fig. 16 に示す。さらに提案した親ロボットの計測目標位置の自動計画 を用いずに，オペレータが手動により親ロボットの位置を決定 した場合の結果の一例も合わせて示す。これより，a）は総移動 距離は短いが，測定回数が多く，測定回数に対するカバー率の 上昇值（計測効率・右図の傾き）は 5.46 [\%/回] であるのに対 

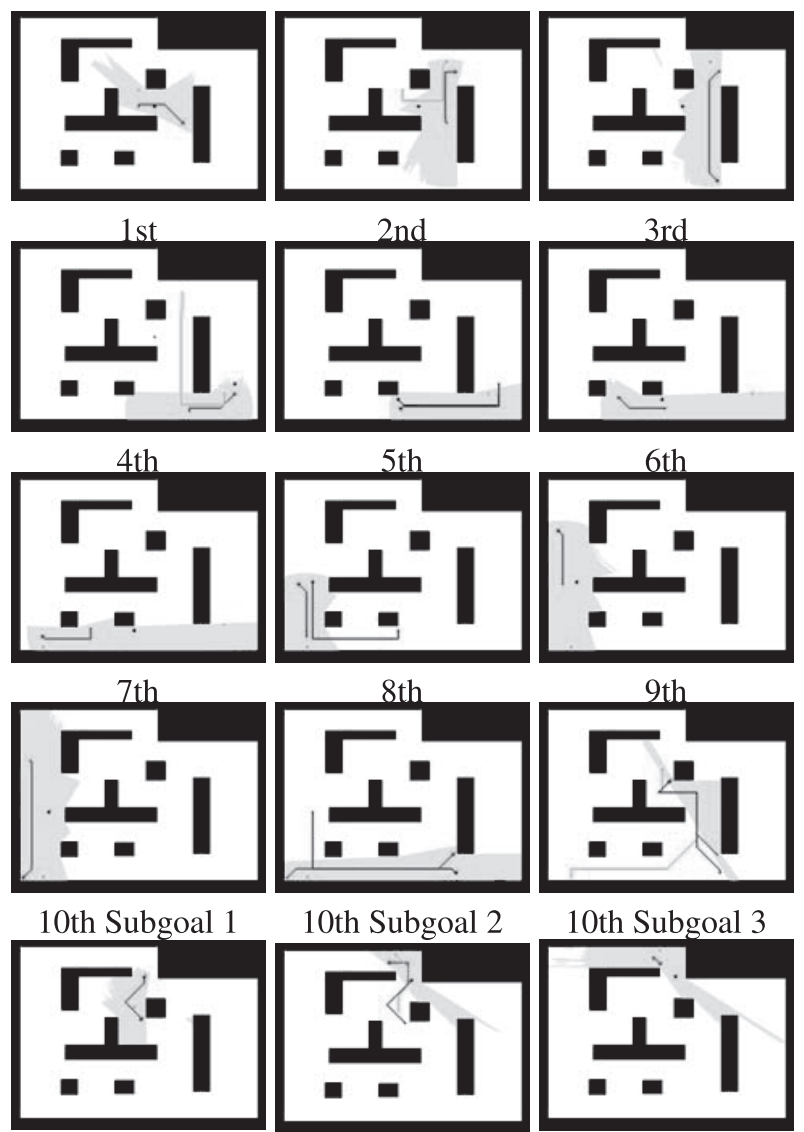

10th Subgoal 2
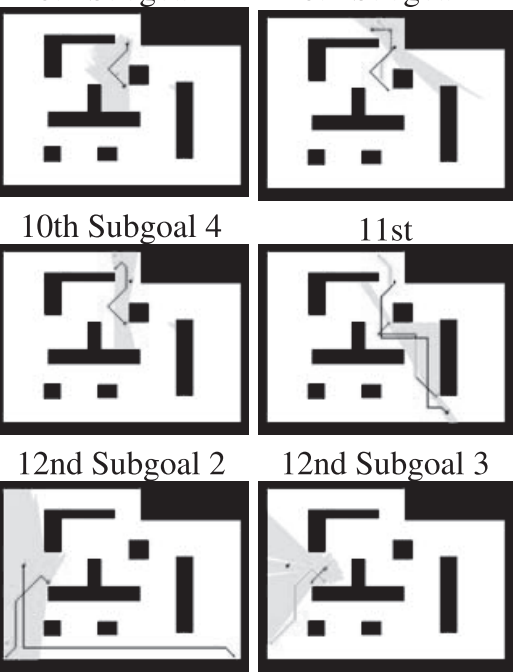

12nd Subgoal 5

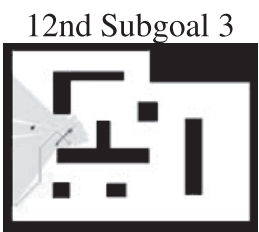

12nd Subgoal 6 10th Subgoal 3
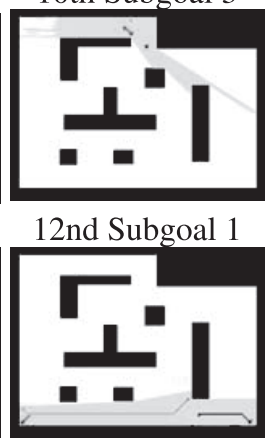

12nd Subgoal 4

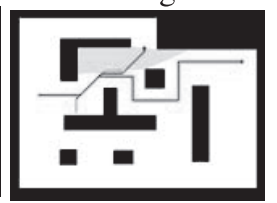

$13 \mathrm{rd}$

Fig. 14 Trajectories of robots in case that a target position where a measurable area is maximized is selected $(\alpha=$ 0 ) for MAP C (1st 13rd measurements)

し，b）は総移動距離が長いが，測定回数が少なく，計測効率は $6.14[\% /$ 回 $]$ であった。一方，人手により決定した手法は，総移 動距離, 測定回数ともに多く, 計測効率は $5.02[\% /$ 回]（5 回平 均）であった。また，移動距離 $1[\mathrm{~m}]$ 当たりのカバー率の上昇 值（移動効率）は，a）が $0.430[\% / \mathrm{m}]$, b) が $0.232[\% / \mathrm{m}]$ で あったのに対し，手動が $0.331[\% / \mathrm{m}]$ （5 回平均）であり, a) は手動に比べて移動効率が $30.2 \%$ 向上した．また，カバー率が $98 \%$ 以上となるまでの計測回数は, a）が 18 回，b）が 16 回に 対し, 手動は19.6 回（5 回平均）であり, b) は手動に比べて 計測回数が $18.4 \%$ 減少した.

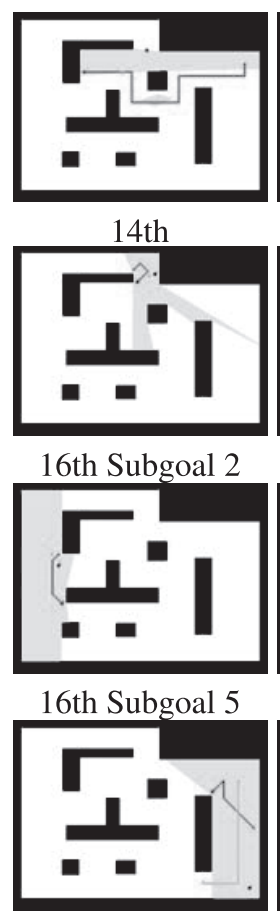

18th Subgoal 1

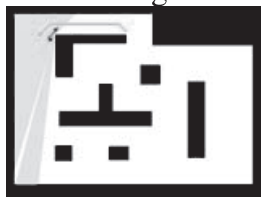

18th Subgoal 4

Fig. 15 Trajectories of robots in case that a target position where a measurable area is maximized is selected $(\alpha=$ 0 ) for MAP C (14th 18th measurements)

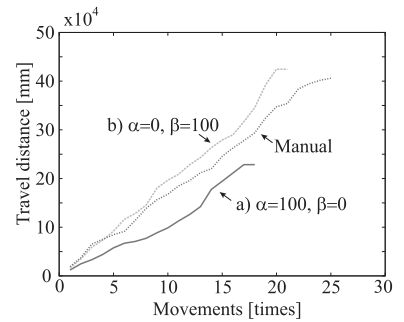

(a) Travel distance

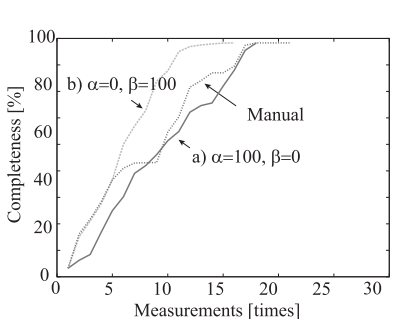

(b) Measured area (cover ratio)
Fig. 16 Comparison of travel distance and measured area of parent robot

\section{1 .2 子ロボットの最適配置}

4.2 節で提案した誤差の蓄積を低減する子ロボットの配置法に ついて，その妥当性を検討するため，式 (2) に执いてパラメー 夕 $\alpha_{c}, \beta_{c}$ を変えてシミュレーションを行い，それぞれのパラ メータと蓄積誤差の関係を調べた。 シミュレーションは，以下 の 4 と打りの条件で行った。

a）永倉らの手法 [25]

b) $\alpha_{c}=1, \beta_{c}=1$ (角度・距離均等)

c） $\alpha_{c}=100, \beta_{c}=1$ (子ロボット間の角度重視）

d） $\alpha_{c}=1, \beta_{c}=100$ (親子ロボット間の距離重視） 


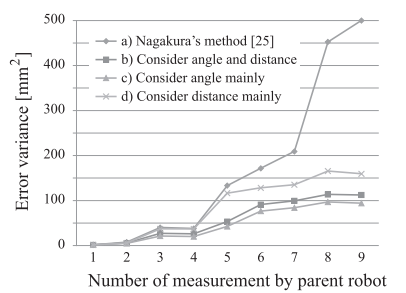

Map A

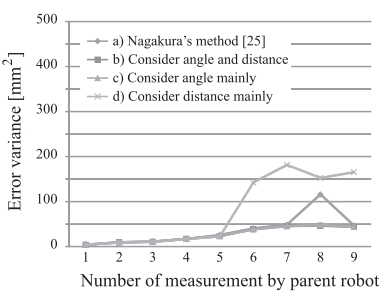

Map B

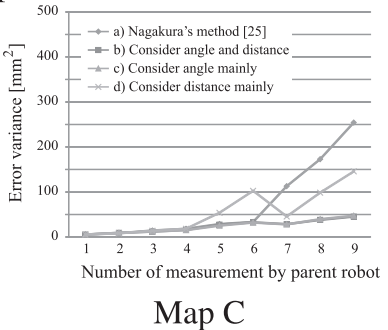

Fig. 17 Comparison of positioning errors

Table 1 Comparison of positioning error variances for MAP A, $\mathrm{B}$, and $\mathrm{C}$ after parent robot moves nine times $\left[\mathrm{mm}^{2}\right]$

\begin{tabular}{|l|r|r|r|r|}
\hline & (a) [25] & (b) angle/distance & (c) angle & (d) distance \\
\hline MAP A & 500.0 & 112.3 & 94.0 & 159.3 \\
\hline MAP B & 46.5 & 43.6 & 43.7 & 165.2 \\
\hline MAP C & 254.2 & 45.3 & 47.2 & 145.8 \\
\hline
\end{tabular}

a）は，式（2）を用いずに，子ロボットをそれぞれCPS が適用 可能な位置にランダムに配置する手法である。またc）では子 ロボット間の角度が $\theta_{\mathrm{t}}=90^{\circ}$ に近い位置が，d）では親・子ロ ボット間の距離が $D_{\mathrm{t}}=3[\mathrm{~m}]$ に近い位置が，それぞれ優先して 目標位置に選ばれるようになっている，また，各ロボットの移 動経路と親ロボットの位置同定誤差の関係は, CPS の誤差伝播 の基本方程式 [26] により計算した. またマップの大きさが 800 × 600 グリッド $(=80[\mathrm{~m}] \times 60[\mathrm{~m}])$ であることから，Pがお よそ0〜 5 グリッド， $L$ がおおよそ $100 \sim 1,000$ グリッド， $S$ が おおよそ 1,000 ～10,000 平方グリッドであると見込み，各項の オーダを揃えるために，親ロボットの目標位置の評価值の係数 は $\beta=0.001$ とした。また，長距離の移動も選択されるように， 移動距離よりも計測領域を優先する5.1.1節（b）に近い条件と して $\alpha=0.01$ とした.

MAP-A における条件ごとの位置同定誤差の蓄積の様子を， Fig. 17 に示す。これより，特に配置の最適化を行わない従来 手法，および距離を重視した場合の誤差が大きく増加している のに対し，角度・距離を均等に評価した場合，および角度を重 視した場合は誤差の蓄積を押さえることができた。 また，親口 ボットが Fig. 9 の×印から観測を開始したとき，すべての地図 に対して計算された 9 回めの移動後の誤差分散值を Table 1 に 示す.これより,

（1）すべての地図で，角度のみ，あるいは角度・距離を均等に 評価した場合は誤差の蓄積が小さい

（2）すべての地図で，距離のみを評価した場合は誤差の蓄積が 大きい

（3）子ロボットの配置をランダムに行う手法 [25] は地図, 試行 間で精度の差が激しい

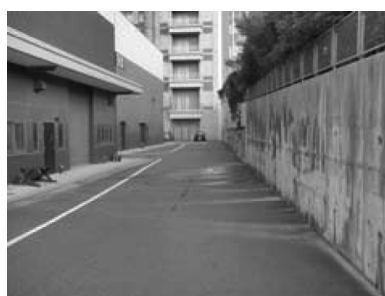

(a)

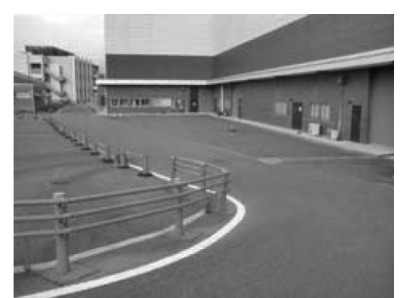

(b)
Fig. 18 Experimental environment

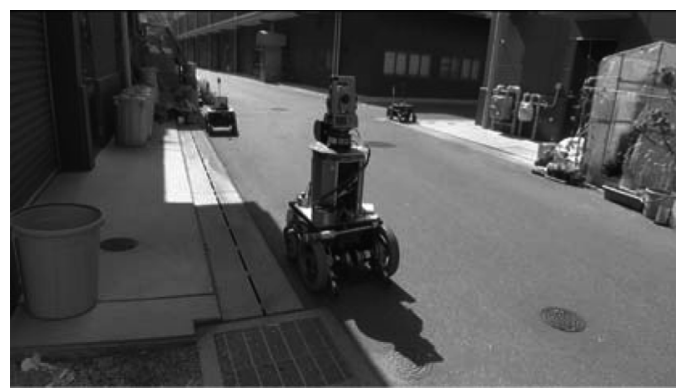

Fig. 19 Outdoor experiment

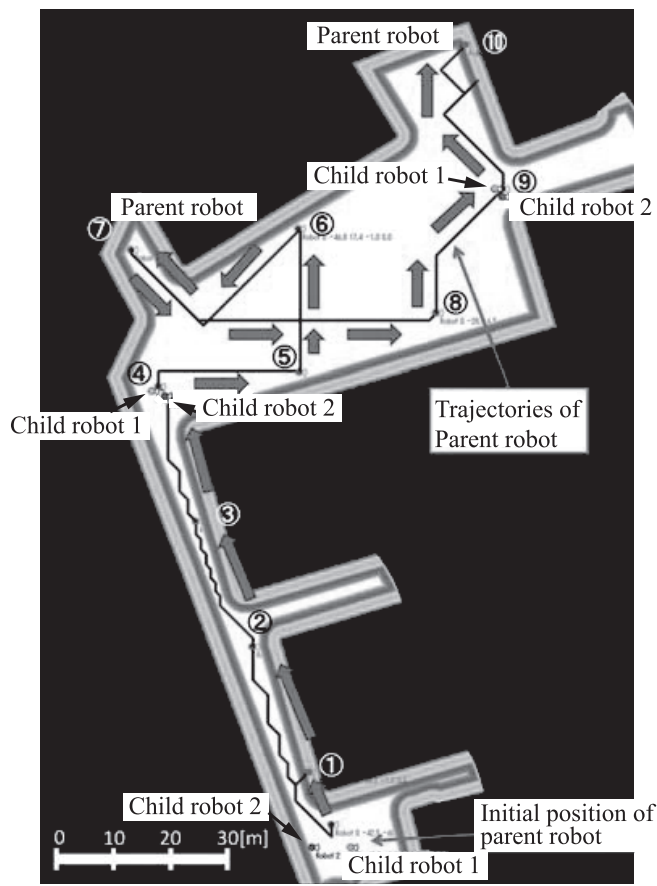

Fig. 20 Trajectories of parent and child robots (case 1)

（4）誤差の蓄積が小さくなるように子ロボットの配置を決定す ることで，安定した精度で計測できる

などのことが分かった。

\section{2 実環境における動作実験}

提案したアルゴリズムを実機（Fig. 2）に搭載し，屋外環境で の確認実験を行った. Fig. 18 に実験環境を示す.また, Fig. 19 に屋外実験の様子を，Fig. 20，21 に計画された親子ロボット の経路を示す。各図中の矢印は移動方向，番号は親ロボットの 


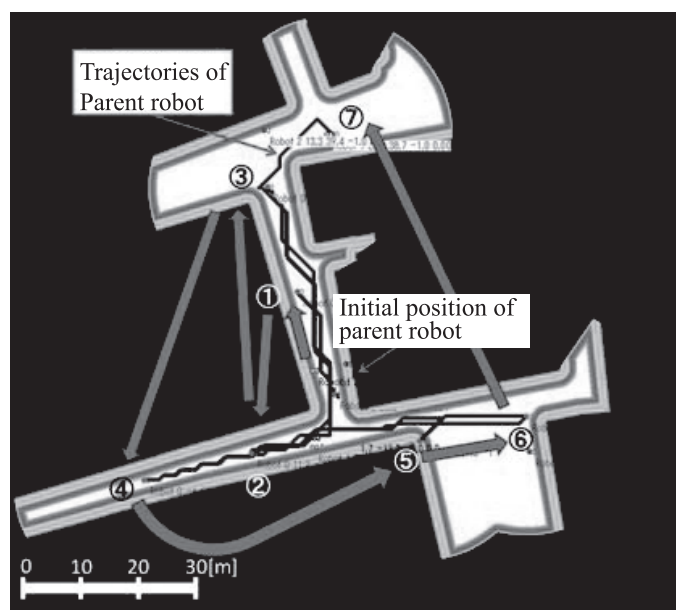

Fig. 21 Trajectories of parent and child robots (case 2)

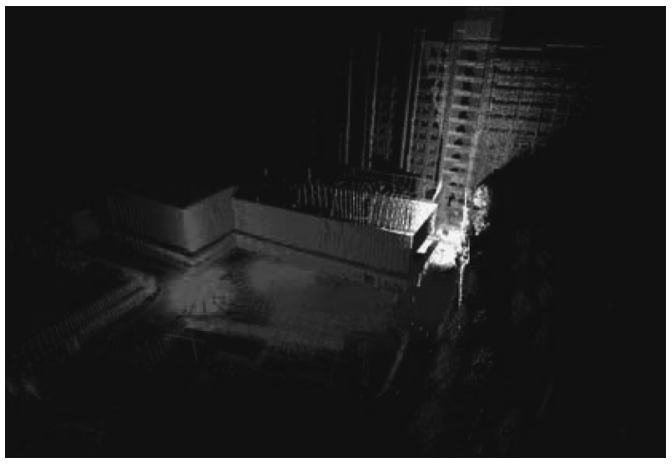

Fig. 22 Obtained 3D model (case 1)
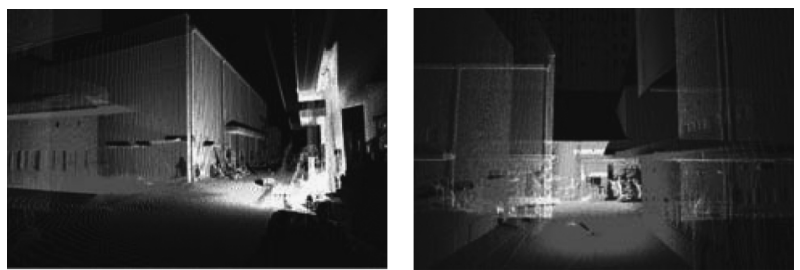

Fig. 23 Obtained 3D model (case 2)

移動回数を示している. Fig. 20 では，親ロボット（実線）は初 期位置から直進して，手前の建物の角で曲がり，開けた空間を 計測した。 子ロボットは，親ロボットが曲がるとき Fig. 200 移動 4 回め) と，開けた場所の奥の方に進んだとき（Fig. 20の 移動 9 回め) に位置を変更した. また, Fig. 21 では, 親ロボッ トが $\mathrm{T}$ 字路の中央から左右に振動しながら計測を行い，最終的 に地図上部の広い通路に移動した。この広い通路のほうへ移動 する際，VisibilityGraph によるサブゴール探索を用いての移 動が 1 回行われた. 子ロボット 1 は Fig. 21 の移動 2, 3, 7 回 め, 子ロボット 2 は移動 $2,4,6,7$ 回めのときに, それぞれ 移動を行った. この動作計画の結果, 最終的にFig. 22, 23 の 三次元地図を構築することに成功した.

さらに，建物を一周する実験を行った，得られた三次元地図 を Fig. 24(a)(b)に，提案手法によって計画された親子ロボッ

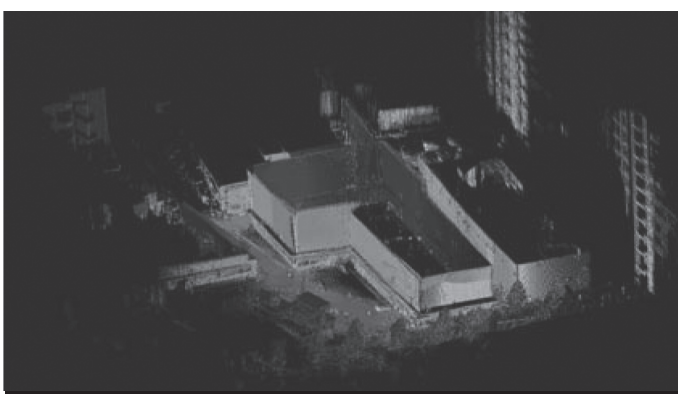

(a) 3D model

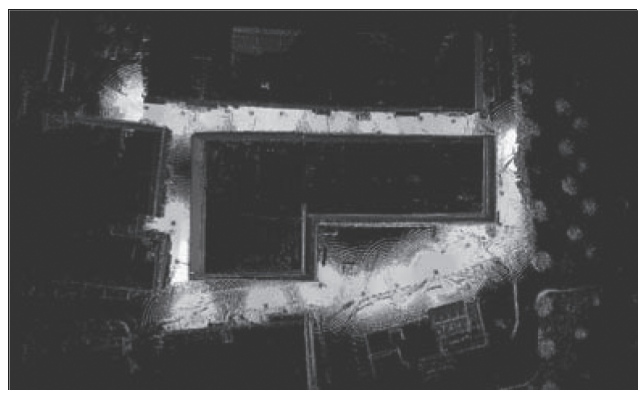

(b) 3D model (Top view)

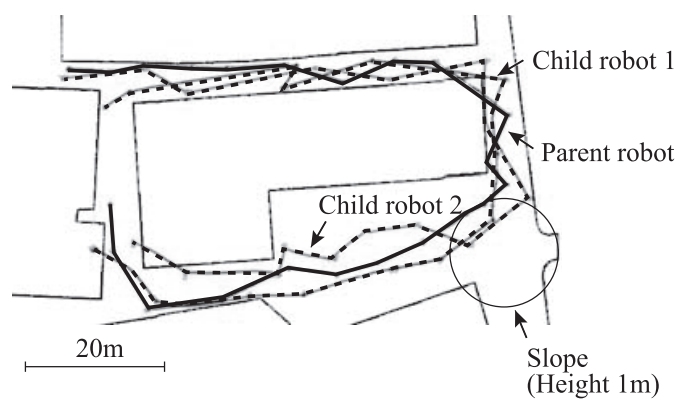

(c) Trajectories

Fig. 24 3D models and trajectories of parent and child robots (case 3)

トの経路を Fig. 24 (c) に示す。親ロボット（実線）は，初期位 置から Fig. 18 (a) の左側の建物周囲を一周し, 移動とともに子 ロボットの位置が逐次計画され (破線), 最終的に計測を自動で 行うことができることを確認した。

なお, Fig. 20，21 の実験は，路面がアスファルトの平坦な場 所で行い, Fig. 24 の実験は図中の丸印で書かれた場所で $1[\mathrm{~m}]$ の高低差がある環境で行った、また，自動車との衝突防止など の安全性の観点から, 実際の実験では，システムが提案手法に 基づき次の観測地点候補を数点提示し，オペレータはその中か ら適当な点を選択することとした。この提示された候補から選 択する手法は, 実際の作業では非常に効率的で, 安心感があり, 提案手法の有効性が確認できた.

\section{6. ま と め}

本論文では，筆者らが開発したCPS-SLAM による大規模環 境のレーザ計測システムに対し, ロボット間の見通しの確保や 位置同定誤差の低減, 効率的な環境計測作業の実現を目指した 自動観測計画の立案手法を提案した。本手法は，親ロボットと 
子ロボットのそれぞれの目標位置選択において, K-means 法に よる目標位置の絞り込みや観測効率性を表す評価值の最適化, AND 領域や Visibility graph を用いたサブゴール設定に基づ く見通しの確保, Voronoi 境界による安全な移動経路の実現な どを行うものである．本論文では，シミュレーションにより提 案手法の有効性を確認するとともに, 実機による動作実験を行 い, 各ロボットが自動で観測計画を立案しながら，三次元環境 地図を取得できることを確認した。

謝 辞 本研究の一部は, 文部科学省科学研究費補助金基盤

研究（A）（課題番号 26249029）の支援を受けた.

\section{参 考 文 献}

[1] 倉爪亮, 戸畑享大, 村上剛司, 長谷川勉 : “CPS SLAM の研究一大 規模建造物の高精度三次元幾何形状レーザ計測システム—”, 日本ロ ボット学会誌, vol.25, no.8, pp.1234-1242, 2007.

[2] Y. Tobata, R. Kurazume, Y. Noda, K. Lingemann, Y. Iwashita and T. Hasegawa: "Laser-based geometrical modeling of large-scale architectural structures using co-operative multiple robots," Autonomous Robot, vol.32, no.1, pp.49-62, 2012.

[3] 鄭龍振, 岩下友美, 倉爪亮: “CPS-SLAM の研究一計測精度の向 上とトンネル出来形計測システムの構築—”, 日本ロボット学会誌, vol.30, no.2, pp.180-187, 2012.

[4] K.A. Tarabanis, P.K. Allen and R.Y. Tsai: "A survey of sensor planning in computer vision," IEEE Trans. on Robotics and automation, vol.RA-11, no.1, pp.86-104, 1995.

[ 5 ] T.S. Newman and A.K. Jain: "A survey of automated visual inspection," Computer Vision and Image Understanding, vol.61, no.2, pp.231-262, 1995.

[6] A. Mavrinac and X. Chen: "Modeling coverage in camera networks: A survey," International journal of computer vision, vol.101, no.1, pp.205-226, 2013.

[7] A. Aggarwal: The art gallery theorem: Its variations, applications, and algorithmic aspects, Ph.D. thesis, Johns Hopkins University, 1984.

[ 8 ] J.O. Rourke: Art Gallery Theorems and Algorithms. Oxford Univ. Press, 1987.

[ 9 ] I. Stamos and P.K. Allen: "Interactive sensor planning," Proc. of the IEEE Computer Society Conference on Computer Vision and Pattern Recognition, pp.489-494, 1998.

[10] H.R. Topcuoglu, M. Ermis and M. Sifyan: "Positioning and Utilizing Sensors on a 3-D Terrain Part I Theory and Modeling," IEEE Trans. on Systems, Man and Cybernetics Part C: Applications and Reviews, vol.41, no.3, pp.376-382, 2011.

[11] S.Y. Chen and Y.F. Li: "Automatic sensor placement for model-based robot vision," IEEE Transactions on Systems, Man and Cybernetics, Part B: Cybernetics, vol.34, no.1, pp.393-408, 2004.

[12] W.R. Scott, G. Roth and J.-F. Rivest: "View planning with a registration constraint," Proc. Third Int. Conf. on 3-D Digital Imaging and Modeling, pp.127-134, 2001.

[13] F. Prieto, T. Redarce, et al.: "CAD-based range sensor placement for optimum 3D data acquisition," Proc. Second Int. Conf. on 3-D Digital Imaging and Modeling, pp.128-137, 1999.

[14] D. Papadopoulos-Orfanos and F. Schmitt: "Automatic 3-D digitization using a laser rangefinder with a small field of view," Conf. on Recent Advances in 3-D Digital Imaging and Modeling, pp.60-67, 1997.
[15] H. Zha, K. Morooka, T. Hasegawa and T. Nagata: "Active modeling of 3-D objects: Planning on the next best pose (NBP) for acquiring range images," Proc. Int. Conf. on Recent Advances 3-D Digital Imaging Modeling, pp.68-75, 1997.

[16] E. Marchand and F. Chaumette: "Active sensor placement for complete scene reconstruction and exploration," Proc. IEEE Int. Conf. on Robotics and Automation, pp.743-750, 1997.

[17] S.Y. Chen and Y.F. Li: "Vision sensor planning for 3-D model acquisition," IEEE Transactions on Systems Man and Cybernetics, Part B: Cybernetics, vol.35, no.5, pp.894-904, 2005.

[18] Y.F. Li and Z.G. Liu: "Information entropy-based viewpoint planning for 3-D object reconstruction," IEEE Transactions on Robotics, vol.21, no.3, pp.324-337, 2005.

[19] R. Bajcsy: "Active perception," Proc. of the IEEE, vol.76, no.8, pp.966-1005, 1988.

[20] Y. Aloimonos, ed.: Active perception. Psychology Press, 2013.

[21] J. Okamoto, M. Milanova and U. Bueker: "Active perception system for recognition of 3D objects in image sequences," 5th Int. Workshop on Advanced Motion Control, pp.700-705, 1998.

[22] 倉爪亮, 広瀬茂男, 岩崎倫三, 長田茂美, 指田直毅 "協調ポジショニ ングシステムの研究—冗長位置情報の融合と機械モデル実験—”, 日 本ロボット学会誌, vol.14, no.8, pp.1229-1236, 1996.

[23] R. Chatila: "Path planning and environment learning in a mobile robot system," Proc. European Conz Artificial Intelligence, Torsey, pp.211-215, 1982.

[24] Mark de Berg et al.: Computational Geometry: Algorithms and Applications. Springer, 1997.

[25] 永倉翔吾，倉爪亮，岩下友美，長谷川勉: “3 次元環境地図構築シス テムに抢ける群ロボットの環境計測作業の自動計画手法”, 第 30 回 日本ロボット学会学術講演会予稿集 DVD-ROM, 1B2-3, 2012.

[26] 倉爪亮, 広瀬茂男, 岩崎倫三, 長田茂美, 指田直敦 : 協調ポジショニ ングシステムの研究—CPS-II 型システムの最適化移動形態—”，日 本ロボット学会誌, vol.15, no.5, pp.773-780, 1997.

[27] F. Aurenhammer and V. Diagrams: "A Survey of a Fundamental Geometric Data Structure," ACM Computing Surveys (CSUR), vol.23, issue 3, pp.345-405, 1991.

[28] J.C. Latombe: Robot Motion Planning. Kluwer Academic Publishers, 1991.

\section{付録 A． 屋内環境における計測実験}

Fig. 25 (a)，（b)に示す屋内環境（ホール）において，提案手 法により計測経路を自動計画した場合と，手動により計画した 場合で計測作業を行った。自動計測によって得られた三次元モデ ルを Fig. 25 (c) に，自動計画と手動計画それぞれの計測経路を Fig. 25 (d), (e) に示す. それぞれの計測回数は, 自動計画が13 回，手動計測が16 回であった. しかし, Fig. 25 (d), (e) を詳し く比較すると, 自動計画では, 細い通路はロボットが通過でき ないと判断されたため，手動計画で計測された左端（Fig. 25 (d) 14 番) や上側の通路 (16 番) のデータが得られていないことが 分かる。 また手動計測では，床面でレーザ光が反射し距離デー 夕が得られにくいため, 操作者の判断で繰り返し計測を行った 箇所（Fig. 25 (d) 2，6 番，3，7 番）もあった。このため，両 者の直接的な比較はできないが, 自動計画では手動計画に比べ てより一定の間隔で均一に計測されていることが分かる. 


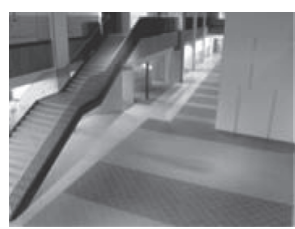

(a) Environment

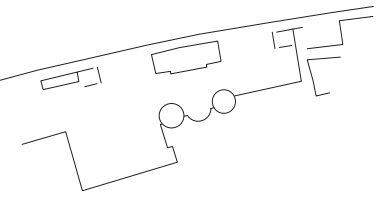

(b) $2 \mathrm{D}$ map

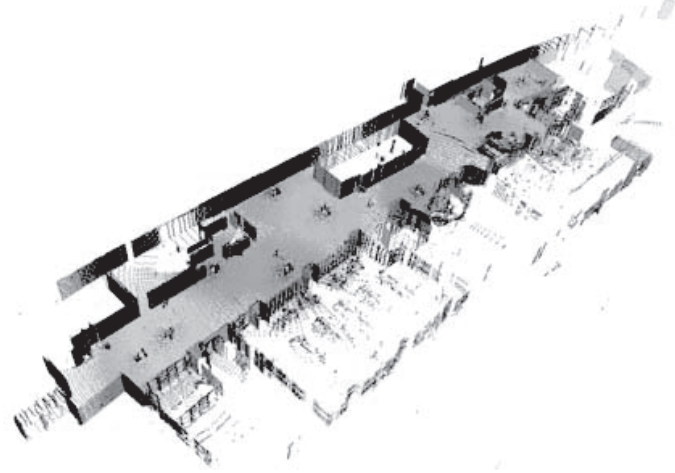

(c) Measured 3D model

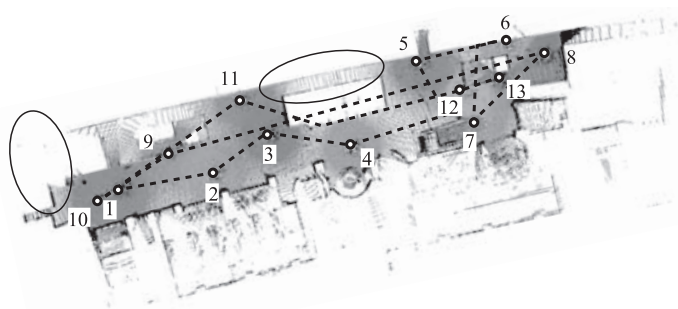

(d) Automatic planning

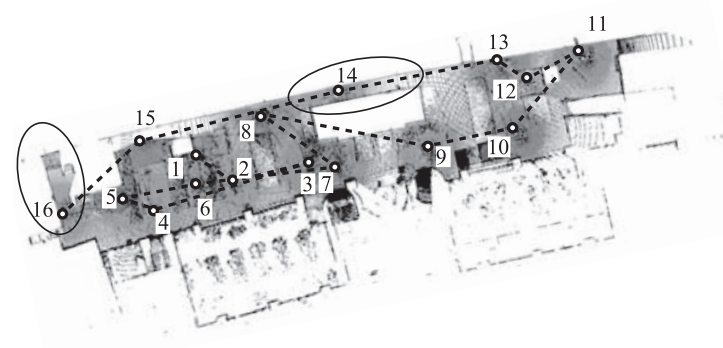

(e) Manual planning

Fig. 25 Example of measurement paths by manual and automatic planning

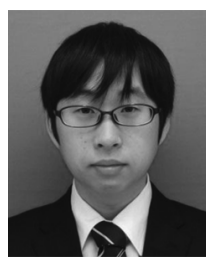

\section{大島漱一郎 (Souichiro Oshima)}

2013 年九州大学電気情報工学科卒業. 現在九州大 学大学院システム情報科学府修士課程在学中. 群ロ ボットによるレーザ計測の研究に従事.

(日本ロボット学会学生会員)

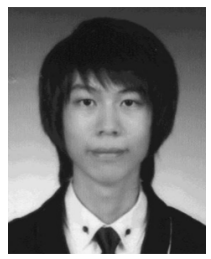

\section{鄭 龍振 (Jeong Yongjin)}

2010 年韓国釡山大学工学部情報コンピュータ工学 科卒業. 2012 年九州大学大学院システム情報科学 府修士課程修了. 2014 年九州大学大学院システム 情報科学府博士後期課程入学. 移動ロボット, 群ロ ボット，レーザ計測の研究に従事.

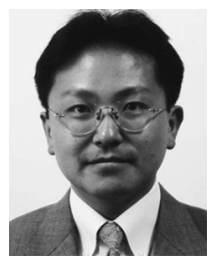

\section{倉爪 亮（Ryo Kurazume）}

1991 年東京工業大学機械物理工学専攻修士課程修 了. 同年 (株) 富士通研究所入社, 1995 年東京工 業大学機械宇宙学科助手, 2000 年スタンフォード 大学客員研究員, 同年東京大学生産技術研究所博士 研究員, 2002 年九州大学システム情報科学研究院 助教授，2007 年より同教授，現在に至る。日本口 ボット学会論文賞 (1993，2014), 日本ロボット学会功労賞 (2008), 日本機械学会ロボティクス・メカトロニクス部門学術業績賞 (2012) 等受賞. 群ロボット，歩行機械，レーザ計測，医療画像処理の研究に 従事. 博士 (工学).

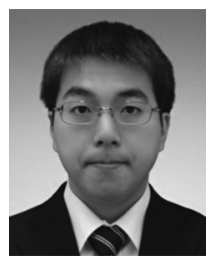

永倉翔吾（Syogo Nagakura）

2013 年九州大学大学院システム情報科学府修士課 程修了．在学中，群ロボットによるレーザ計測の研 究に従事.

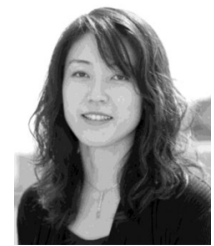

岩下友美（Yumi Iwashita）

2007 年九州大学大学院システム情報科学府知能シ ステム学専攻博士課程修了. 日本学術振興会特別研 究員, Imperial College London 客員研究員を経 て，同年より九州大学大学院システム情報科学研究 院助教, 現在に至る. 2011 年から NASA ジェット 推進研究所客員研究員 (2015 年まで). コンピュー タビジョンの研究に従事。博士 (工学)。（日本ロボット学会正会員） 